Vol. 8 (2). Mayo - Agosto. Hamut'ay 2021. Lima-Perú

\title{
Editorial
}

\section{Tecnologías de la Información y la Comunicación en Educación:}

\author{
Impactos y Desafíos
}

\section{Information and Communication Technologies in Education: Impacts and Challenges.}

\author{
Cleofé Genoveva Alvites Huamaní ${ }^{1}$ \\ https://orcid.org/0000-0001-6328-6470 \\ Editor en jefe de la revista científica Hamut'ay \\ Universidad Alas Peruanas, Perú
}

\section{Cita Recomendada}

Alvites-Huamaní, C., (2021). Tecnologías de la información y la comunicación en educación: Impactos y desafíos. Hamut'ay, 8 (2), 5-10, http://dx.doi.org/10.21503/hamu.v8i2.2287

\section{Introducción}

La sociedad a nivel global ha sufrido cambios abruptos por la pandemia (Hernández, 2020) que ha azotado a todos los continentes, y que continua con la aparición de nuevas variantes del coronavirus, situación que no ha impedido el retorno a actividades educativas, económicas o laborales (Brítez, 2020), al disminuir muchas de las restricciones existentes, dando paso a una nueva normalidad.

En el contexto educativo, muchos países se vieron obligados a realizar una reestructuración al haber pasado a una educación totalmente virtualizada, debido al cierre de las escuelas como estrategia para la no propagación del virus, hecho que conllevo a dar primacía a las Tecnologías de la Información y la Comunicación (TIC), como único medio que permitía brindar el servicio educativo y llegar a cada uno de los lugares donde se tenía acceso a conectividad, sin importar el espacio ni el tiempo, desplazándose la escuela a los hogares.

Después de casi dos años, en la mayoría de los países, las instituciones educativas que impartían clases en línea, se vieron abocadas a prepararse para regresar a la presencialidad en el espacio físico que dejaron por esta crisis sanitaria, en el

\section{Introduction}

Society at a global level has suffered from abrupt changes due to the pandemic (Hernández, 2020) that has hit all continents, although it still continues to face the new variants of the coronavirus, but despite this, activities have had to resume both economic, labor and educational, (Britez, 2020) because many of the restrictions have been lifted, giving way to a new normal.

In the educational context, many countries were forced to carry out a restructuring after having switched to a totally virtualized education, due to the closure of schools in order that the virus did not continue to spread, which led to giving primacy to the technologies of information and communication, as it was the only means that allowed to continue providing the educational service and to reach each the places where there was access to connectivity, regardless of space or time, and homes became schools, (Narodowski and Campetella, 2020).

After almost two years that in most countries, educational institutions only have an online space to teach classes, now they must prepare to return to the physical space that they left due to this health crisis and in which technologies were a secondary school in the teaching-learning

1. Editor en jefe de la revista científica Hamut’ay. Investigador Renacyt - Concytec. Universidad Alas Peruanas, Perú 
que las TIC eran secundarias dentro del proceso de enseñanza-aprendizaje, dado que para muchos docentes no era necesario poseer competencias digitales y no estaban obligados a utilizar estas tecnologías. Sin embargo, el panorama cambio, y los docentes fueron forzados a desarrollar estas competencias para impartir sus sesiones virtualmente y a la vez tener una interacción más efectiva de docentes y estudiantes con los contenidos del curso (Bustos y Coll, 2019).

\section{Impactos de las Tecnologías de la información y Comunicación en Educación}

Por las condiciones actuales, el principal o más evidente impacto que han tenido las TIC en la educación, es la dependencia de ellas (Fernández-Batanero et al., 2021), lo que ha llevado a cambiar el perfil del estudiante y el rol de docente. Los docentes tuvieron que transformar su metodología de enseñanza al tener que utilizar recursos y herramientas tecnológicas con componentes interactivos, sincrónicos y asincrónicos (Jiménez-Álvarez et al., 2021), llevándolos a desarrollar competencias tecnológicas y digitales que antes no poseían o que eran incipientes, y a apropiarse rápidamente de las tecnologías requeridas para sus sesiones de clases, como repositorios de información, bases de datos, laboratorios o simuladores, con el propósito de lograr con los objetivos propuestos en sus planes de clases con sus estudiantes (Fernández y Balonas, 2021).

Por su parte los estudiantes de un momento a otro, vieron que un espacio de su hogar se convertía en su salón de clase y su celular era el medio para realizar esa interacción con docentes y compañeros a través de diversas plataformas y medios tecnológicos. Pero no solo fue su ambiente físico el que cambio, sino además el tener que pasar de ser consumidor a prosumidor, debido a que debería enviar sus tareas y actividades académicas utilizando las TIC sin importar si su nivel educativo era inicial, primaria, secundario o universitario.

No solo las TIC per se han impactado a la educación, sino también los servicios que se process, and in which many of the teachers did not need to have digital skills and were less obliged to use technologies, but the panorama changed considering that teachers were forced to develop these skills because they had to teach their sessions virtually and at the same time have a more effective communication between the course contents, teachers and students, (Sánchez and Salvador, 2019).

\section{Impacts of Information and Communication} Technologies in Education

The main or most evident impact on education is the dependence on technology, (FernándezBatanero et al., 2021) because education is teach on line, which has led to a change in the student's profile and role. of teacher.

Teachers had to make changes in their teaching method by having to use technological resources and tools making use of interactive, synchronous and asynchronous components (Jiménez-Álvarez et al., 2021), develop technological and digital skills that he did not possess them or they were incipient, having to adapt quickly (Fernández and Balonas, 2021) to the appropriation of technologies for their class sessions, from the search for information, tools or technological resources or databases or laboratories, simulators that would allow them to achieve with the objectives proposed in your lesson plans with your students.

For their part, the students from one moment to another, saw that a space in their home became their classroom and their cell phone was the means to carry out that interaction with their teacher and classmates through a variety of platforms and technological means to use. But it was not only his physical environment that changed, but also having to go from being a consumer to a prosumer, because he should send his assignments and academic activities using technologies regardless of the educational level, be preschool, primary, secondary or university. Not only information and communication technologies per se have affected education, but also the resources that make use of it, within these 
brindan a través de ellas, dentro de estas destacan redes sociales viralizadas para el uso educativo como Facebook y WhatsApp (Almonacid-Fierro et al., 2021; Martínez, Mosqueda y Saucedo, 2020).

La tecnología móvil es otro componente que se ha integrado en el proceso enseñanza-aprendizaje, al ser un aliado para el docente por promover aprendizaje autónomo, por tener una serie de aplicaciones o el permitir bajar otras a sugerencia del docente, (Zamora, 2019).

\section{Desafíos de las Tecnologías de la Información y Comunicación en Educación}

Han sido muchos los desafíos que ha tenido que enfrentar la educación desde el momento que se volvió a distancia por el confinamiento generado a nivel mundial. Es así que se tuvieron que implementar nuevas metodologías de enseñanza para dar continuidad a los procesos educativos (Schwartzman et al., 2021). Metodologías como el aula invertida, el aprendizaje basado en proyectos y el aprendizaje colaborativo mediados por las TIC, han facilitado los aprendizajes y dado otra perspectiva al proceso de enseñanza aprendizaje (Fernández-Esteban et al., 2021).

El mobile learning o aprendizaje móvil es otra estrategia que ha incursionado en la educación y que utiliza como herramienta tecnológica al móvil, al brindar un bagaje de apps que permiten al estudiante tener una interactividad e interacción con recursos que tiene el mismo dispositivo o que el docente sugiere para cumplir con sus objetivos planteados en sus asignaturas, (Pinto-Molina, Caballero-Mariscal y GarcíaMarco, 2021).

A pesar de que muchos gobiernos están haciendo los esfuerzos por controlar la pandemia, parece que seguirá presente por varios años, y por ello será necesario seguir replanteándose la enseñanza presencial, con enfoques como el aprendizaje híbrido o blended learning, en el que se combina la presencialidad análoga con la online (Sousa, Peset y Muñoz-Sepúlveda, 2021).

Las tecnologías han venido a aquedarse en el ámbito educativo, si antes no se pensó en que social networks stand out, which became viral for educational use, such as the cases of Facebook and WhatsApp. (Almonacid-Fierro et al., 2021; Martínez, Mosqueda and Saucedo, 2020).

Mobile technology is another component that it has been integrated into the teachinglearning process, being an ally for the teacher by promoting autonomous learning, by having a series of applications or by allowing others to be downloaded at the teacher's suggestion, (Zamora, 2019).

\section{Challenges of Information and Communication Technologies in Education}

There have been many challenges that education has had to face since it was transformed into a distance education due to the confinement that was had worldwide by the pandemic, which generated that new teaching methodologies had to be implemented to continuity of education, (Schwartzman et al., 2021).

Teaching mediated by technologies has allowed a greater emphasis on implementing methodologies such as flipped classroom, project-based learning, collaborative learning, which facilitated learning, giving another perspective to the teaching-learning process of hybrid education (Fernández-Esteban et al., 2021).

Mobile learning or M-learning is another strategy that has ventured into education and that uses mobile as a technological tool, by providing a wealth of apps that allow the student to have interactivity and interaction with resources that the same device or that of the teacher has. suggests to meet their goals set in their subjects, (Pinto-Molina, Caballero-Mariscal and GarcíaMarco, 2021).

Despite that many governments are making efforts to control the pandemic, it seems that it will still be with us for a few years, which is one of the challenges that education will have to continue facing, because face-to-face teaching will have to be rethought, since it is being planned to be a hybrid or blended teaching because it will have to combine face-to-face with online teaching, 
se tuviera esta como un medio, actualmente esta se perfila como tal, debido a que ya se ha implantado una educación hibrida, en el que el modelo educativo tradicional se ha combinado con el aprendizaje en línea, en la que tantos docentes como estudiantes participan de manera presencial como remota, (Guaman, Villareal y Cedeño, 2020).

Pero, no solo es organizar, planificar, cambiar o adaptar metodologías, sino que también los docentes han tenido que reinventar sus estrategias de enseñanza, y situar recursos y herramientas tecnológicas para sus sesiones de clases sincrónicas o asincrónicas, para hacerlas interactivas, dinámicas, de fácil uso y acceso (Jiménez-Álvarez et al., 2021). Además, han tenido que discernir sobre qué plataformas utilizar para la interacción entre docenteestudiante y estudiante-estudiante, con el fin de brindar un abanico de posibilidades para el autoaprendizaje (Flores-Tena, Ortega-Navas y Sousa-Reis, 2020).

Otro aspecto a tener en cuenta por la educación, es el tema de conectividad, por el riesgo que se tiene de generar mayores brechas educativas, al no contarse con infraestructura tecnológica idónea de acuerdo con las condiciones geográficas en que se encuentran los estudiantes (Montenegro, Raya y Navaridas, 2020).

Las TIC, a pesar de las adversidades en el tema salud, avizoran tiempos mejores en el ámbito educativo, al haber posibilitado alternativas para cambiar la percepción que tenían muchos docentes acerca de ellas, y pasar a ser vistas como aliadas y no como una obstrucción a su desempeño académico.

\section{Referencias Bibliográficas}

Almonacid-Fierro, A., Vargas-Vitoria, R., Mondaca, J. y Sepúlveda-Vallejos, S., (2021). Prácticas profesionales en tiempos de pandemia Covid-19: Desafíos para la formación inicial en profesorado de Educación Física. Retos, 42, 162-171.

Brítez, M., (2020) La educación ante el avance del COVID-19 en Paraguay. Comparativo con países de la Triple Frontera. Universidad Nacional
(Sousa, Peset and Muñoz-Sepúlveda, 2021).

Technologies have come to stay in the educational field, if before it was not thought of having this as a means, now it is emerging as such, because a hybrid education has already been implemented, where the traditional educational model It has been combined with online learning, in which both teachers and students take part in person and remotely (Guaman, Villareal and Cedeño, 2020).

Not only is it organizing, planning, changing or adapting methodologies, but it also implies a strong challenge for teachers, who have had to reinvent their teaching strategies, for which they have had to place resources and technological tools for their synchronous or asynchronous class sessions., which had the characteristic of being interactive, dynamic, easy to use and access, (Jiménez-Álvarez et al., 2021). But also, it must also discern which platforms to use to add these, and in turn allow an interaction between teacher-student and student-student. Because it has not only implied a challenge for the teacher but also for the student by providing a range of interaction possibilities for their self-learning, (Flores-Tena, Ortega-Navas and Sousa-Reis, 2020).

One of the greatest challenges that education must take on with force is the issue of connectivity, which has generated without proposing a greater gap in education, because it does not have suitable technology infrastructure and the geographical scope does not help the use of these technologies, (Montenegro, Raya and Navaridas, 2020).

Information and communication technologies, despite the adversities in the health issue, are anticipating better times in the educational field, since it achieves accepted point of view changes in many teachers related to technologies, seeing this as their ally and not an obstruction to their academic performance. 
del Este. https://doi.org/10.1590/SciELOPreprints. 22

Dussel, Inés; Ferrante, Patricia y Pulfer, Darío (comps.), Pensar la educación en tiempos de pandemia. Entre la emergencia, el compromiso y la espera, (2020). Educación y destrucción creativa en el capitalismo de pospandemia. Narodowski. M. y Campetella, D. Buenos Aires, Unipe: Editorial Universitaria.

Fernández Souto, A. y Balonas, S. (2021). La creatividad en la enseñanza como factor de aproximación de la universidad a los desafíos sociales. Icono 14, 19(2), 11-35. https://doi.org/10.7195/ ri14.v19i2.1754

Fernández-Batanero, J.M., Román-Graván, P., Montenegro-Rueda, M., \& Fernández-Cerero, J. (2021). El impacto de las TIC en el alumnado con discapacidad en la Educación Superior. Una revisión sistemática (2010-2020). EDMETIC, Revista de Educación Mediática y TIC, 10(2), 81-105.https://doi.org/10.21071/edmetic. v10i2.13362

Fernández-Esteban, I., Bethencourt-Aguilar, A., Martín-Gómez, S., Becerra-Brito, C. \& Area-Moreira, M. (2021). Percepciones sobre el impacto educativo de la COVID-19: Análisis de un Webinar de la Cátedra TECNOEDU International Journal of Educational Research and Innovation (IJERI), 15, 519-532 ISSN: 2386-4303. https:// doi.org/10.46661/ijeri.5732

Montenegro, S., Raya, E. y Navaridas, F. (2020). Percepciones Docentes sobre los Efectos de la Brecha Digital en la Educación Básica durante el Covid -1. Revista Internacional de Educación para la Justicia Social, 9(3e), 317-333. https://doi. org/10.15366/riejs2020.9.3.017

Flores-Tena, M.J., Ortega-Navas, M. y Sousa-Reis, C. (2020). El uso de las TIC digitales por parte del personal docente y su adecuación a los modelos vigentes. Revista Electrónica Educare, 25(1), 1-21. https://doi.org/10.15359/ree.25-1.16 Guaman, R. Villareal, A. Cedeño, E. (2020). La Educación Híbrida como alternativa frente al Covid -19 en el Ecuador. Revista de Investigación Científica TSE'DE, 3(1), 134-147.

Hernández, J. (2020). Impacto de la COVID-19 sobre la salud mental de las personas. Medicent 
Electrón, 24 (3), 578-594.

Jiménez-Álvarez, L., Fierro-Jaramillo, N., Quichimbo-Miguitama, P. y Capa-Mora, D., (2021). Impacto de las estrategías de aprendizaje en educación a distancia sobre el desempeño estudiantil en un curso introductorio de la ciencia del suelo. Educare, 25(2), 1-16. https://doi.org/10.15359/ ree.25-2.6

Martínez, V., Mosqueda, N., y Saucedo, V. (2020). Las redes sociales y su impacto en los universitarios, Revista de Desarrollo Sustentable, Negocios, Emprendimiento y Educación RILCO, (4). https://www.eumed.net/rev/rilcoDS/04/redes-sociales.html

Pinto-Molina, M.; Caballero-Mariscal, D. y García-Marco, F. J. (2021). Evaluación de la implantación de las aplicaciones móviles en las universidades española. Revista Española de Documentación Científica, 44 (1), e286. https://doi. org/ 10.3989/redc.2021.1.1755

Sánchez, A. y Salvador, C. (2019) Los entornos virtuales como espacios de enseñanza y aprendizaje. Una perspectiva psicoeducativa para su caracterización y análisis, Revista Mexicana de Investigación Educativa, 14 (44) pp. 163-184.

Schwartzman, G., Roni, C., Berk, M., Delorenzi, E., Sánchez, M., y Eder, M. L. (2021). Evaluación Remota de Aprendizajes en la Universidad: decisiones docentes para encarar un nuevo desafío. RIED. Revista Iberoamericana de Educación a Distancia, 24(2), 67-85. https://doi.org/10.5944/ ried.24.2.29078

Zamora, R. (2019). El M-Learning, las ventajas de la utilización de dispositivos móviles en el proceso autónomo de aprendizaje. Rehuso, 4(3), 29-38. https://revistas.utm.edu.ec/index.php/Rehuso/article/view/1982 